\title{
DENDROCLIMATIC POTENTIAL OF PLAINS COTTONWOOD (POPULUS DELTOIDES SUBSP. MONILIFERA) FROM THE NORTHERN GREAT PLAINS, USA
}

\author{
JESSE EDMONDSON ${ }^{1,3}$, JONATHAN FRIEDMAN $^{1}$, DAVID MEKO ${ }^{2}$, RAMZI TOUCHAN ${ }^{2}$, JULIAN SCOTT $^{1}$, and \\ ALAN EDMONDSON ${ }^{3}$ \\ ${ }^{1}$ U.S. Geological Survey, Fort Collins Science Center, Fort Collins, CO, 80526-8118, USA \\ ${ }^{2}$ Laboratory of Tree-Ring Research, University of Arizona, Tucson, AZ, 85721, USA \\ ${ }^{3}$ Tree-Ring Laboratory, University of Arkansas, Fayetteville, AR, 72701, USA
}

\begin{abstract}
A new 368-year tree-ring chronology (A.D. 1643-2010) has been developed in western North Dakota using plains cottonwood (Populus deltoides subsp. monilifera) growing on the relatively undisturbed floodplain of the Little Missouri River in the North Unit of Theodore Roosevelt National Park. We document many slow-growing living trees between 150-370 years old that contradict the common understanding that cottonwoods grow fast and die young. In this northern location, cottonwood produces distinct annual rings with dramatic interannual variability that strongly crossdate. The detrended tree-ring chronology is significantly positively correlated with local growing season precipitation and soil moisture conditions $(r=0.69)$. This time series shows periods of prolonged low radial tree growth during the known droughts of the instrumental record (e.g. 19311939 and 1980-1981) and also during prehistory (e.g. 1816-1823 and 1856-1865) when other paleoclimate studies have documented droughts in this region. Tree rings of cottonwood will be a useful tool to help reconstruct climate, streamflow, and the floodplain history of the Little Missouri River and other northern river systems.
\end{abstract}

Keywords: Dendrochronology, North Dakota, Little Missouri River, PDSI, riparian, floodplain.

\section{INTRODUCTION}

Few tree-ring chronologies are available from the Northern Great Plains for reconstructing past climate in this drought-prone province of North America (Figure 1). More in situ paleoclimate proxy data would be beneficial for better understanding the natural spatial and temporal variability of drought in this area. Although this region is lacking in trees, some opportunities exist for dendroclimatic research. Previous tree-ring research in the Great Plains has largely focused on the remnant escarpment woodlands, including ponderosa pine (Pinus ponderosa), rocky mountain juniper (Juniperus scopulorum), and eastern red cedar (Juniperus virginiana) (Weakly 1943, 1971; Stockton and Meko 1983; Sieg et al. 1996; Woodhouse and Brown 2001; Edmondson 2010). Here we present a chronology based on rings of the riparian tree plains cottonwood (Populus deltoides subsp. monilifera).

Riparian tree species have typically been avoided for climate reconstruction for a variety of reasons. Trees growing at or near the water table typically produce complacent annual rings that are not useful for reconstructing growingseason moisture variability (Stokes and Smiley 1996; Fritts 2001). However, tree-ring investigations using baldcypress (Taxodium sp.) in the southeastern United States, Mexico, and Guatemala have shown that in spite of frequently flooded conditions, these chronologies are sensitive to growing-season precipitation (Stahle et al. 1988, 2011, 2012; Stahle and Cleaveland 1992; Villanueava-Diaz et al. 2007). Others have shown that the annual ring width of floodplain cottonwood trees is related to flow and precipitation 


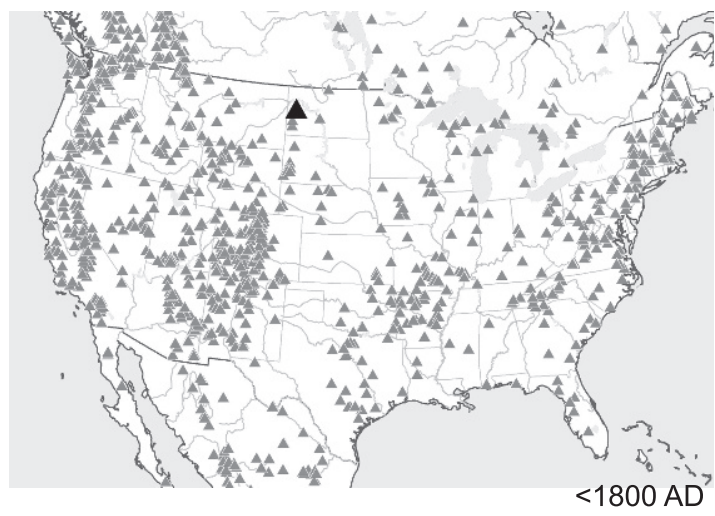

Figure 1. The available tree-ring chronologies for North America dating before A.D. 1800 are illustrated (small gray triangles; data from International Tree-Ring Data Bank 2012). The new Populus deltoides subsp. monilifera chronology from west-central North Dakota is the only available plains cottonwood proxy record for this period from the entire network and is located in an area of the northern Great Plains lacking paleoclimate data (large black triangle).

(Reily and Johnson 1982; Dudek et al. 1998; Yu et al. 2011).

Populus has also been avoided for paleoclimate studies because its annual ring boundaries can be indistinct especially where winters are mild (Maingi 2006) and because many forests lack trees over 150 years old (Bradley and Smith 1986; Cordes 1991; Scott et al. 1997; Stromberg 1998: Maingi 2006). However, Everitt (1968) reported that in the cold dry climate of North Dakota, plains cottonwood trees grow slowly and live longer than 250 years. Others working with narrowleaf cottonwood ( $P$. angustifolia), balsam poplar ( $P$. balsamifera), and black cottonwood $(P$. trichocarpa) in the northern US and Canada have documented ages of 200 to more than 300 years (Thomas and Podmore 1953; Shaw 1976; Nanson and Beach 1977; Peterson et al. 1996; Rood and Polzin 2003; Merigliano 2007; Merigliano et al. 2013). There are currently no plains cottonwood chronologies available on the International TreeRing Data Bank (ITRDB), and only one short eastern cottonwood chronology ( $P$. deltoides ssp. deltoides) developed by J.C. King along the Moreau River in South Dakota (ITRDB 2012). Chronologies have been developed using Populus balsamifera on the Alaskan North Slope (Edwards and Dunwiddie 1985), P. tremuloides in the boreal forest of Canada (Hogg et al. 2005), and shortlived $P$. tremuloides in Wisconsin (Cole et al. 2009).

Another problem with making climate-sensitive tree-ring chronologies of cottonwood is human disturbance. The riparian forests of the Great Plains have been impacted by the clearing of land for agriculture, floodplain inundation by reservoirs, lowered water tables, decreased streamflow, cattle grazing, and flow alterations from operation of upstream dams (Karl et al. 2009). Impacted cottonwood forests are often composed of a few sparsely scattered older trees in decline with little recruitment of new cottonwoods (Auble et al. 2005), and variation in ring width is influenced by human disturbance as well as climate. Therefore, climate reconstruction requires distinguishing the effects of human disturbance from those of climate or selecting a forest in a relatively undisturbed watershed where the effects of human disturbance are relatively minor.

This paper presents recent research along the Little Missouri River in the North Unit of Theodore Roosevelt National Park. The scope of the broader study is to document the floodplain history of the Little Missouri River within the North Unit of the park using dendrochronology (1) to date cottonwood recruitment and floodplain formation along the river, and (2) to establish an exactly dated tree-ring chronology that can be used to potentially reconstruct forest, climate, and streamflow history in the park. The focus here will be on developing the tree-ring chronology and exploring its potential to reconstruct past climate for western North Dakota.

\section{STUDY AREA}

The site is located along an $18-\mathrm{km}$ stretch of the Little Missouri River floodplain within the North Unit of Theodore Roosevelt National Park (THRO), North Dakota $\left(47^{\circ} 35^{\prime} \mathrm{N}, 103^{\circ} 23^{\prime} \mathrm{W}\right)$. The floodplain is approximately $1.5 \mathrm{~km}$ wide within steep badlands. The climate in the watershed is semiarid. In Grassy Butte, North Dakota, mean annual precipitation is $38.7 \mathrm{~cm}$, and the wettest months are May and June; average January minimum temperature is $-14.4^{\circ} \mathrm{C}$, and 
average July maximum temperature is $28.7^{\circ} \mathrm{C}$ (National Weather Service Weather Station \#323705). Peak flow along the Little Missouri usually occurs in late March or early April as a result of snow melt and ice break up, but in some years the annual peak occurs later as a result of rainfall, especially in May and June. Extreme events common to this area include blizzards, flooding from ice jams, wind storms, and severe thunderstorms. The river can cease to flow in the late summer of particularly dry years.

The dominant tree species along this section of the Little Missouri River include plains cottonwood, rocky mountain juniper, green ash (Fraxinus pennsylvanica), and peachleaf willow (Salix amygdaloides). Sandbar willow (Salix exigua) is associated with young cottonwood along the active channel, and the ash and juniper are associated with late-successional cottonwood forest on the higher floodplain surfaces. Between these two zones, cottonwoods are typically found in pure stands (Johnson et al. 1976).

The site has been federally protected since 1935. In addition, the river drainage upstream of the park is fairly unaltered in comparison to most across the Great Plains, and there are no large reservoirs in the watershed. Working within this site, Everitt (1968) was the first to show that floodplain surfaces could be dated by aging the cottonwood trees growing upon them. He reported that cottonwood establishes in even-aged bands and that the different-aged bands track the gradual movement of the active river channel across the floodplain. He documented that all age-classes were present, ranging from young trees found along the active channel and lower floodplain surfaces, to large, slow-grown trees $>250$ years old.

\section{METHODOLOGY}

The Little Missouri River floodplain and active channel were delineated within the North Unit of THRO using historic satellite imagery and aerial photographs. A total of 500 points were randomly selected within the defined floodplain boundary. At each point, the closest living cottonwood without heart rot was cored with a Swedish increment borer and measured for diameter (DBH), both at breast height. Coring the largest trees required use of a long increment borer $(1.0 \mathrm{~m})$. At least two cores were taken from each tree to ensure at least one core was near pith and to help avoid problems with crossdating. The field work for this study occurred during JulyAugust and October of 2010. The outermost ring was only considered complete on the samples collected in October.

All cores were mounted and then sanded with progressively finer sand paper from 100 to 600 grit (15 microns). A master dating plot was established for the site using the skeleton-plot method of crossdating (Stokes and Smiley 1996). Cores were then visually crossdated against the established record using the signature patterns of ring width. The dated cores were measured to $0.01 \mathrm{~mm}$ precision with a sliding-stage micrometer and submitted to program COFECHA for quality control (Holmes 1983; Grissino-Mayer 2001).

Ring-width indices for individual cores were conservatively detrended in ARSTAN (Cook 1985) using a $67 \%$ cubic smoothing spline to remove biological growth trends while preserving climaterelated variability, and the resulting ratio-indices of core ring width were averaged into a standard site chronology using the bi-weight mean (Cook 1985). The expressed population signal (EPS) computed in ARSTAN was used to estimate the strength and reliability of the chronology through time, particularly for periods when sample size was low (Wigley et al. 1984; Briffa and Jones 1990). The EPS increases in strength with sample size and with strength of the mean correlation. The minimum value of 0.85 suggested by Wigley et al. (1984) was used in order to identify the best replicated portions of the chronology.

The Matlab program, SEASCORR (Meko et al. 2011), was used to relate the annual growth signal of the cottonwood chronology to local monthly precipitation and temperature (daily maximum) averages from the PRISM climate data set (Daly et al. 2008). SEASCORR was applied such that the precipitation signal is summarized with correlations and the temperature with partial correlations by adjusting for dependence of the tree-ring index and temperature on precipitation. Statistical significance of the correlations and 

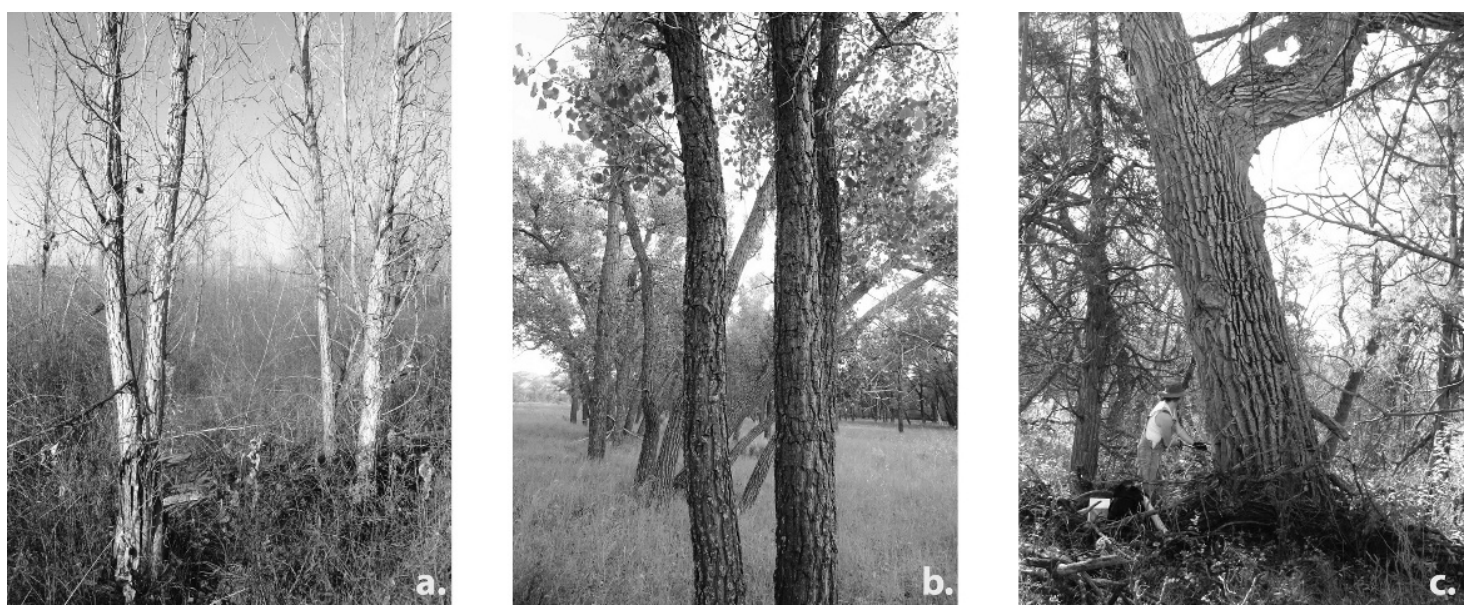

Figure 2. Photographs representing the three main stages of cottonwood forest succession found along the Little Missouri River, North Dakota, including (a) young trees near the active channel, (b) mature trees surrounded by open meadows, and (c) the oldest known plains cottonwood surviving on a high floodplain surface surrounded by green ash and juniper.

partial correlations in SEASCORR is estimated using Monte Carlo simulations (Meko et al. 2011). The spatial correlation of the new cottonwood chronology with growing season soil moisture over North America was tested against the $0.5^{\circ} \times$ $0.5^{\circ}$ gridded Heim instrumental PDSI data set from NOAA (Stahle et al. 2011). Tree-ring data will be contributed to the ITRDB after all initial studies have been completed.

\section{RESULTS AND DISCUSSION}

The riparian corridor along the Little Missouri River in the North Unit of THRO is a relatively undisturbed cottonwood forest with all age classes of trees present. Point bars are dominated by seedlings, saplings, and small trees surrounded by thick patches of willow (Figure 2a). Cottonwoods here are typically $<10 \mathrm{~cm} \mathrm{DBH}$ and are $<15$ years old. The lower and younger floodplain surfaces contain bands of even-aged cottonwood stands separated by sage meadows, with most trees ranging from $10-50 \mathrm{~cm}$ DBH and 20-125 years old (Figure 2b). The higher floodplain surfaces have older and larger cottonwoods, usually ranging from 125-225 years old, within a forest dominated or codominated by green ash and juniper. The oldest cottonwoods (225+ years) are found on the highest floodplain surfaces that occur either within a thick ash/juniper forest or sparsely scattered on sage flats (Everitt 1968; Johnson et al. 1976; Figure 2c). Most of the oldest trees suffered various intensities of heart rot.

A total of 394 of the 500 randomly selected floodplain points were suitable for sampling. The successfully cored trees ranged from $3.8-144.0 \mathrm{~cm}$ DBH (Figure 3; note the largest diameter measured at the site was $166.3 \mathrm{~cm}$, but the tree was hollow). Overall there is a strong correlation at the site between diameter and tree age $\left(\mathrm{R}^{2}=0.79\right.$; Figure 3). The oldest tree documented at the site

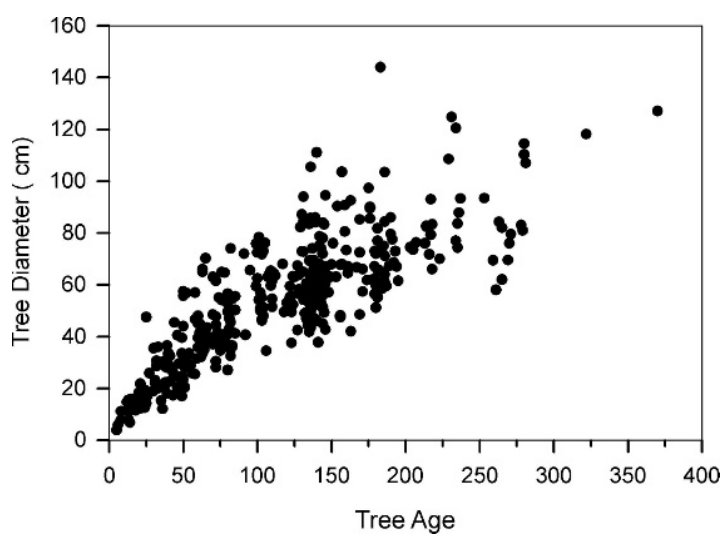

Figure 3. Plains cottonwood (Populus deltoides subsp. monilifera) $\mathrm{DBH}$ as a function of age, North Unit of Theodore Roosevelt National Park, ND ( $\mathrm{n}=383$ trees). 


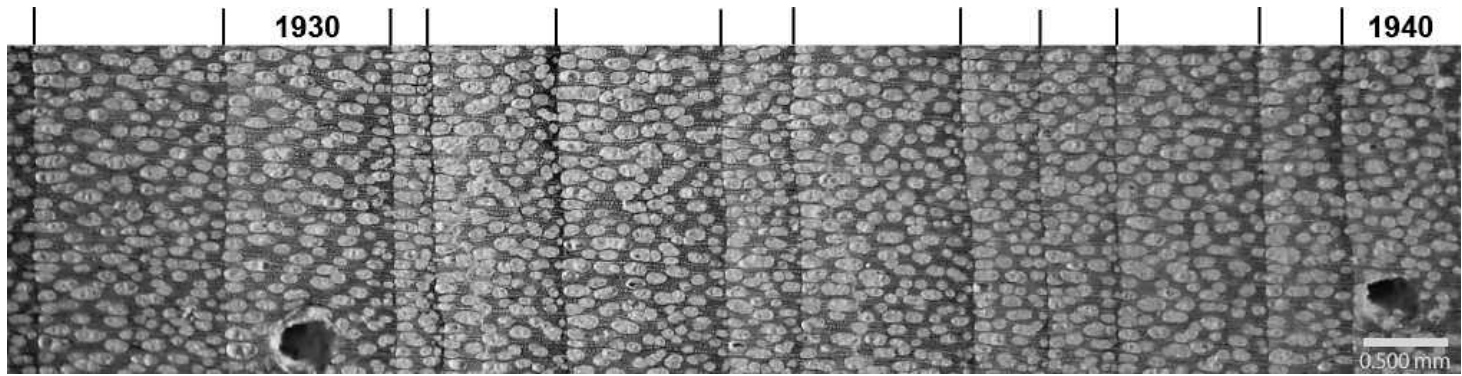

Figure 4. Photomicrograph from a core sample of plains cottonwood (Populus deltoides subsp. monilifera) collected at Theodore Roosevelt National Park showing the slow growth of this tree during the Dust Bowl drought (1931-1939). Cottonwoods growing at this site form distinct annual rings that are sensitive to growing season moisture.

was 370 years old, making it the oldest plains cottonwood ever documented, and had the second largest diameter at the site $(127.0 \mathrm{~cm}$, Figure $2 \mathrm{c})$. Even though the relationship between age and diameter was strong, the age range associated with any diameter was large. For example, trees with $60 \mathrm{~cm}$ diameter ranged in age from about 60 to 275 years old. In addition to large diameter, observed indicators of old age included deeply furrowed bark even high in the tree, missing portions of the canopy, helical twist of the mainstem, and large limbs (Merigliano et al. 2013). The old Populus deltoides at this site and along the Redwater River in Montana (Merigliano 2007) contradict the observation of Rood and Polzin (2003) that Populus of Section Aigeros are shorter-lived than Populus of Section Tacamahaca. We agree with these authors that northern trees will tend to be longer-lived than southern trees because of slower growth in the north.

Cottonwood trees growing at the THRO North Unit produce well-defined diffuse-porous annual rings with exceptional interannual variability (Figure 4). The average measured annual growth ring from the full sample was $1.7 \mathrm{~mm}$, and ranged from 0 to $14.8 \mathrm{~mm}$. The mean annual growth rates were also highly variable among trees, ranging from 0.69 to $5.23 \mathrm{~mm} \mathrm{year}^{-1}$.

The final crossdated chronology covers the period A.D. 1643-2010, and consists of 493 measured radii from 270 randomly sampled trees (see Table 1 for COFECHA statistics). The chronology is considered to be robust back to A.D. 1744 based on the EPS threshold. A separate "climatic" chronology was also developed using only trees $\geq 100$ years old to avoid excessive damping of low-frequency (e.g. multi-decadal scale) features in the site chronology by the spline-detrending (Table 1). The standardized chronology derived in ARSTAN is presented in Figure 5 and shows the long-term natural variability of plains cottonwood growth in western North Dakota for the past 350 years. The most striking feature of the time series is the dramatic swing from prolonged below-average to aboveaverage growth conditions in the early 19th Century. Three out of the ten worst and best growth years in the entire record occurred within an eleven-year span [worst $=1819(1), 1818(2)$, and 1817(6); best $=1828(1), 1826(4)$, and 1829(8)]. Other prolonged periods of low growth include the 1690s, 1790s, 1860s, 1930s, and 1980s. Additional

Table 1. The COFECHA descriptive statistics for the THRO "full floodplain" and "flood plain trees $\geq 100$ years old" measured series data sets.

\begin{tabular}{lcccccccc}
\hline Data Set & $\begin{array}{c}\text { Inner } \\
\text { Ring }\end{array}$ & $\begin{array}{c}\text { Outer } \\
\text { Ring }\end{array}$ & $\begin{array}{c}\text { Number } \\
\text { of Radii }\end{array}$ & $\begin{array}{c}\text { Number } \\
\text { of Trees }\end{array}$ & $\begin{array}{c}\text { Interseries } \\
\text { Correlation }\end{array}$ & $\begin{array}{c}\text { Mean } \\
\text { Sensitivity }\end{array}$ & $\begin{array}{c}\text { Mean } \\
\text { Series Length }\end{array}$ & $\begin{array}{c}\text { Average } \\
\text { Ring Width }\end{array}$ \\
\hline Full FP & 1643 & 2010 & 493 & 270 & 0.68 & 0.353 & 134.5 & $1.71 \mathrm{~mm}$ \\
FP $(\geq 100)$ & 1643 & 2010 & 346 & 189 & 0.69 & 0.348 & 159.0 & $1.55 \mathrm{~mm}$ \\
\hline
\end{tabular}



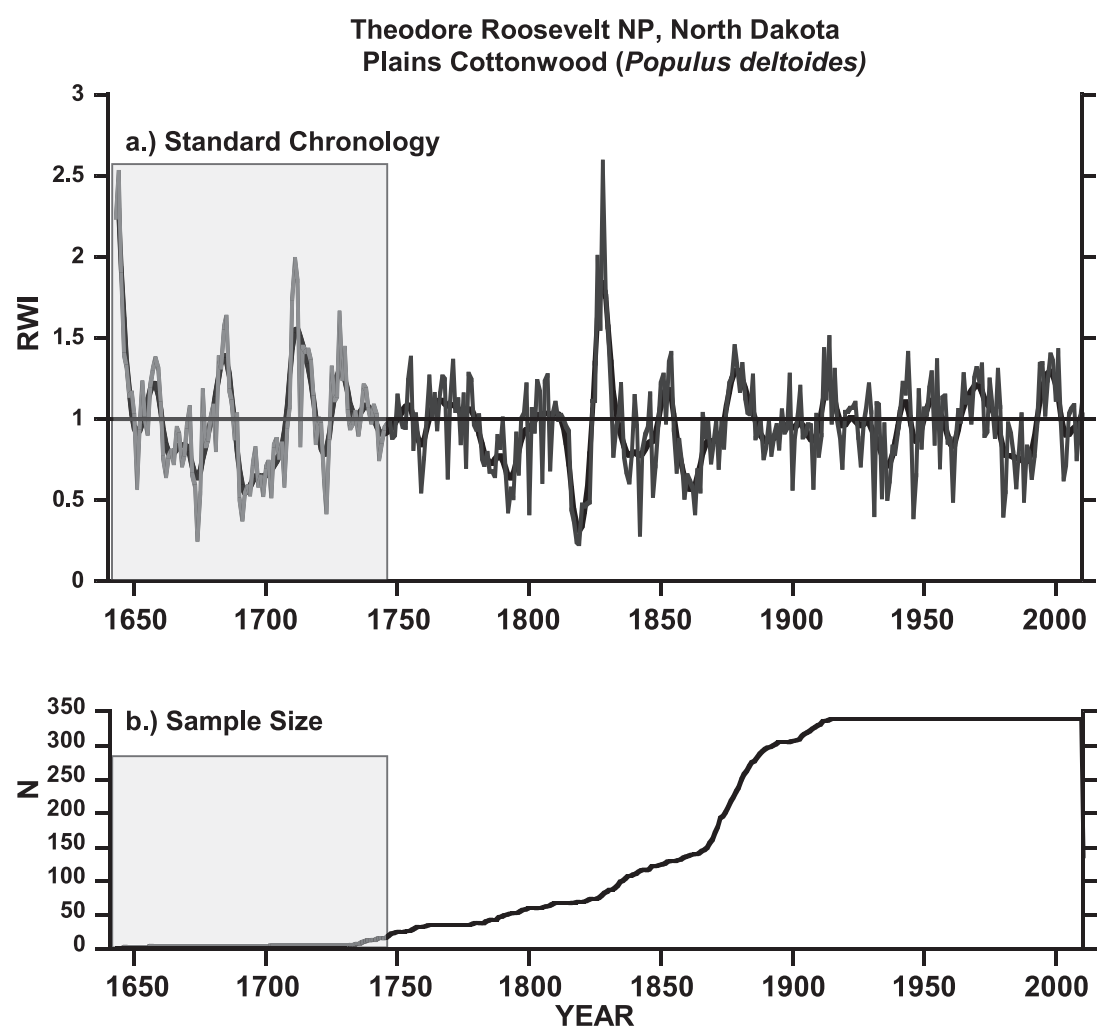

Figure 5. (a) The A.D. 1643-2010 standardized tree-ring chronology (gray line) derived from randomly sampled trees at THRO that were $\geq 100$ years old. The 10-year smoothing spline (black line) highlights decadal periods of high and low radial tree growth. (b) The sample size represented in the above chronology $(\mathrm{n}=346)$. Note the shaded portion in both figures corresponds to when EPS $<0.85$.

periods of above-average growth conditions occurred during the early 1700 s, in $1875-1885$, in 1965-1975, and during the 1990s.

The detrended tree-ring chronologies (climatic version) were correlated against local climate data from PRISM using SEASCORR. Both the standard and residual tree-ring chronologies were used for this analysis. As expected, given the low autocorrelation of monthly and seasonal-total precipitation in the region, the residual chronology was more highly correlated than the standard chronology with precipitation. Climate signal analysis indicates that cottonwood from THRO is useful in reconstructing climate for western North Dakota (Figure 6). Cottonwood at our site responded strongly to water availability; growth was strongly positively correlated with spring/ summer precipitation and less strongly and negatively correlated with spring/summer temper- ature. The correlation between precipitation and growth is strong April-July, but not in August and September, reflecting the growth cessation of this species in July (Reily and Johnson 1982; Friedman et al. 2011). Climate-growth correlations were increased by using 4,6 , and 12-month averages, particularly with precipitation. The 12-month average of precipitation ending in July of the growth year explained $>45 \%$ of the variance in growth.

Given the strong response of our chronology to water availability, we used the averaged JuneJuly Palmer Drought Severity Index (PDSI), for further climate analysis. PDSI is a measurement of soil moisture that is based on recent precipitation and temperature (Palmer 1965). Because PDSI is inherently autocorrelated, the THRO standard chronology was used for spatial correlation analysis with the $0.5^{\circ} \times 0.5^{\circ}$ gridded PDSI data set from 


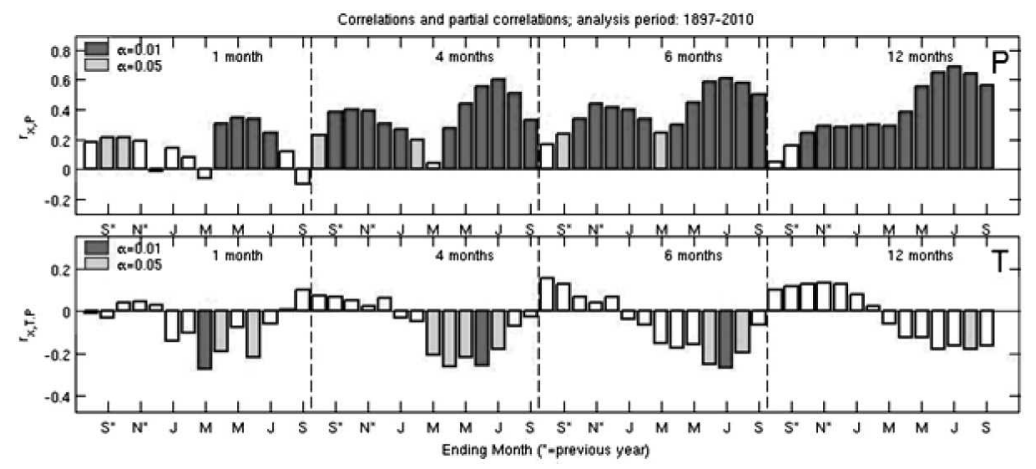

Figure 6. Climate signal analysis showing correlations and partial correlations from SEASCORR between the THRO residual chronology and local monthly precipitation ( $\mathrm{P}$, top) and temperature ( $\mathrm{T}$, bottom) data from PRISM. Statistics are plotted for varying 1, 4, 6, and 12 monthly groupings ending in months ranging from August of the year preceding growth to September of the growth year (month of year preceding growth year is denoted by "*” along the $\mathrm{x}$-axis). The $\mathrm{y}$-axis, $\mathrm{r}_{x, \mathrm{P}}$ for the top plot is the Pearson, or product-moment, correlation between the tree-ring index $(x)$ and monthly or seasonal-total precipitation (P). The y-axis, $r_{x, \text { T.P }}$ for the bottom plot is the partial correlation of $x$ with monthly temperature or seasonal-average temperature $(\mathrm{T})$ after both $\mathrm{x}$ and $\mathrm{T}$ have been adjusted for removal of linear dependence on P. Correlations significant at the $99 \%$ and $95 \%$ confidence levels are shown in dark and light gray, respectively. Chronology version for analysis is FP100 (see text), and analysis period is 1897-2010.

Heim at NOAA (Figure 7). The spatial correlation map indicates that the THRO standard tree-ring chronology is significantly correlated with JuneJuly PDSI over a large area of the northern Great Plains and could possibly reconstruct nearly $50 \%$ of the variability in summer PDSI for an important drought region of North America that is lacking in situ paleoclimate proxy data.

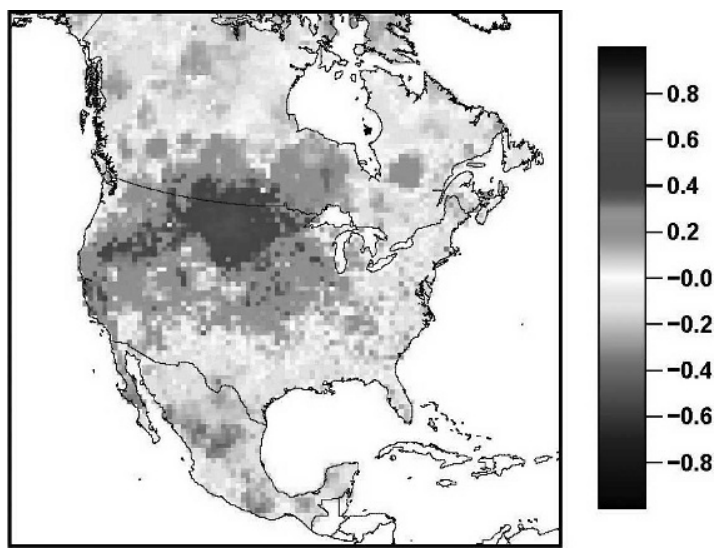

Figure 7. A spatial correlation map between the THRO standardized ring-width chronology and averaged June-July PDSI across North America using the Heim $0.5^{\circ} \times 0.5^{\circ}$ gridded data set (1931-2005) illustrates the strong relationship between annual radial tree growth at our site with summer soil moisture across the Northern Great Plains $\left(r_{\max }=0.69\right)$.
The new cottonwood chronology from western North Dakota can also be compared with the other available tree-ring records and drought reconstructions from the Great Plains region. The closest available time-series for comparison are $J$. scopulorum and $P$. ponderosa developed by Sieg et al. (1996) from sites $<100 \mathrm{~km}$ away. All of the significant periods of low and high growth present in our tree-ring record are also found in these two nearby chronologies. The prolonged period of low growth during 1816-1823 in our chronology corresponds with many tree-ring records of drought from the Great Plains (Weakly 1943, 1971; Stockton and Meko 1983; Blasing and Duvick 1984; Cleaveland and Duvick 1992; Meko 1992; Cook et al. 2007; Edmondson 2010). This period also corresponds to historic observations of dune activity reported by Muhs and Holliday (1995) and historic descriptions of the Great Plains as the "Great American Desert" by the Long expedition in 1818-1820 (Stockton and Meko 1983; Cook et al. 2007). Lakota winter counts in 1818-1819 described that period as the "sand-blowing years" in their historical records from this region (Therrell and Trotter 2011). This period of slow growth and the subsequent swing to prolonged above-average growth conditions in our chronology are also similarly documented by others (Stockton and Meko 1983; Meko 1992; Fye et al. 2003; Therrell 
and Trotter 2011). Stockton and Meko (1983) described several swings from drought to pluvial in their climate reconstruction from the Great Plains, and noted the most drastic was a pluvial in 1825-1835 that followed drought in 1815-1825. Another noteworthy comparison of our cottonwood chronology to this record is that both indicate that the 1820 s and 1860 s droughts were more severe than any from the 20th Century including the Dust Bowl, which is commonly regarded as the drought of record for the Great Plains.

\section{CONCLUSIONS}

The North Unit of THRO contains a naturally functioning floodplain ecosystem including the oldest known living plains cottonwood tree and abundant trees $>150$ years old. We found that cottonwood at this site is suitable for dendrochronology and succeeded in making the longest known cottonwood tree-ring chronology (A.D. 1643-2010). Our preliminary analysis of the climate signal recorded by cottonwood annual growth rings indicates that our chronology is sensitive to growing season moisture availability and will be useful in reconstructing climate and potentially streamflow for this region of western North Dakota.

The utility of cottonwood for climate reconstruction increases northward because northern trees appear to live longer and have more distinct ring boundaries than southern trees. Discovery of Populus more than 200 years old along the Snake, Green, Yellowstone and Redwater rivers (Merigliano et al. 2013) suggests there is strong potential to expand the network of cottonwood chronologies in the northern Great Plains to rivers with major importance for water supply.

\section{ACKNOWLEDGMENTS}

Funding was provided by the National Park Service Climate Change Response Program, the National Park Service Water Resources Division and the US Geological Survey National Climate Change and Wildlife Science Center. Reviews were provided by Patrick Anderson and two anonymous referees. John Heiser, Laurie Richardson and Bill
Whitworth of Theodore Roosevelt National Park provided essential logistical support. Daniel Griffin helped with Figure 1. David Stahle and Dorian Burnette assisted with the spatial correlation map for Figure 7. Jeff Hughes and Michael Merigliano made important contributions to study design, and Ben Everitt inspired the study by his example. Any use of trade, firm, or product names is for descriptive purposes only and does not imply endorsement by the US Government.

\section{REFERENCES CITED}

Auble, G., M. Scott, J. Frazier, C. Krause, and M. Merigliano, 2005. Cottonwood in the Missouri Breaks National Monument. US Geological Survey Fact Sheet 2005-3132; 4 pp.

Blasing, T. J., and D. N. Duvick, 1984. Reconstruction of precipitation history in North American Corn Belt using treerings. Nature 307:143-145.

Bradley, C., and D. Smith, 1986. Plains cottonwood recruitment and survival on a prairie meandering river floodplain, Milk River, southern Alberta and northern Montana. Canadian Journal of Botany 64:1433-1442.

Briffa, K. R., and P. D. Jones, 1990. Basic chronology statistics and assessment. In Methods of Dendrochronology: Applications in the Environmental Sciences, edited by E. R. Cook, and L. A. Kairiukstis, pp. 137-152. Kluwer Academic Publishers, Dordrecht.

Cleaveland, M. K., and D. N. Duvick, 1992. Iowa climate reconstructed from tree rings, 1640-1982. Water Resources Research 28:2607-2615

Cole, C. T., J. E. Anderson, R. L. Lindroth, and D. M. Waller, 2009. Rising concentrations of atmospheric $\mathrm{CO}_{2}$ have increased growth in natural stands of quaking aspen (Populus tremuloides). Global Change Biology 16:2186-2197.

Cook, E. R., 1985. A Time Series Approach to Tree-Ring Standardization. Ph.D. dissertation, University of Arizona, Tucson.

Cook, E. R., R. Seager, M. A. Cane, and D. W. Stahle, 2007. North American drought reconstructions, causes, and consequences. Earth Science Reviews 81:93-134.

Cordes, L. D., 1991. The distribution and age structure of cottonwood stands along the lower Bow River, Alberta. In Proceedings of the Biology and Management of Southern Alberta's Cottonwoods Conference, Lethbridge, Alberta, 4-6 May 1990, edited by S. B. Rood, and J. M. Mahoney, pp. 13-24. University of Lethbridge, Lethbridge, Alberta.

Daly, C., M. Smith, J. I. Smith, W. P. Gibson, M. K. Doggett, G. H. Taylor, J. Curtis, and P. P. Pasteris, 2008. Physiographically-sensitive mapping of temperature and precipitation across the conterminous United States. International Journal of Climatology 28:2031-2064.

Dudek, D. M., J. R. M. Lenahen, and W. J. Mitsch, 1998. Tree growth responses of Populus deltoides and Juglans nigra to streamflow and climate in a bottomland hardwood forest in central Ohio. American Midland Naturalist 140:233-244. 
Duvick, D. N., and T. J. Blasing, 1981. A dendroclimatic reconstruction of annual precipitation amounts in Iowa since 1680. Water Resources Research 17:1183-1189.

Edmondson, J. R., 2010. Long Tree-Ring Chronologies for the Central Great Plains, U.S.A. M.S. thesis, University of Arkansas, Fayetteville.

Edwards, M. E., and P. W. Dunwiddie, 1985. Dendrochronological and palynological observations on Populus balsamifera in Northern Alaska, U.S.A. Arctic and Alpine Research 17:271-278.

Everitt, B. L., 1968. Use of the cottonwood in an investigation of the recent history of a flood plain. American Journal of Science 266:417-439.

Fritts, H. C., 2001. Tree-Rings and Climate. Blackburn Press, Caldwell, New Jersey; 584 pp.

Grissino-Mayer, H. D., 2001. Evaluating crossdating accuracy: a manual and tutorial for the computer program COFECHA. Tree-Ring Research 57:205-221.

Hogg, E. H., J. P. Brandt, and B. Kochtubajda, 2005. Factors affecting interannual variation in growth of western Canadian aspen forests during 1951-2000. Canadian Journal of Forest Research 35:610-622.

Holmes, R. L., 1983. Computer-assisted quality control in treering dating and measurement. Tree-Ring Bulletin 43:69-78.

Johnson, W. C., R. L. Burgess, and W. R. Keammerer, 1976. Forest overstory vegetation and environment on the Missouri River floodplain in North Dakota. Ecological Monographs 46:59-84.

Karl, T. R., J. M. Melillo, and T. C. Peterson, 2009. Global Climate Change Impacts in the United States. Cambridge University Press, 196 pp.

Maingi, J. K., 2006. Growth rings in tree species from the Tana River floodplain, Kenya. Journal of East African Natural History 95:181-211.

Meko, D. M., 1992. Dendroclimatic evidence from the Great Plains of the United States. In Climate since A.D. 1500, edited by R. S. Bradley, and P. D. Jones, pp. 312-330. London and New York, Routledge.

Meko, D. M., R. Touchan, and K. J. Anchukaitis, 2011. Seascorr: A MATLAB program for identifying the seasonal climate signal in an annual tree-ring time series. Computers and Geosciences 37:1237-1241.

Merigliano, M. F., 2007. Senescent Cottonwoods along the Redwater River: Possible Causes that could Guide Remedies. Report to the McCone Conservation District, Circle, Montana.

Merigliano, M. F., J. M. Friedman, and M. L. Scott, 2013. Tree-ring records of variation in flow and channel geometry. In Treatise on Geomorphology, edited by J. Shroder, Jr., C. Hupp, and D. Butler, pp. 145-164. Academic Press, San Diego, California.

Nanson, G. C., and H. F. Beach, 1977. Forest succession and sedimentation on a meandering river floodplain, northeast British Columbia, Canada. Journal of Biogeography 4: 229-251.

Palmer, W. C., 1965. Meteorological Drought. Weather Bureau Research Paper 45, US Dept. of Commerce, Washington, DC; $58 \mathrm{pp}$.
Peterson, E. B., N. M. Peterson, and D. S. McLennan, 1996. Black Cottonwood and Balsam Poplar Managers' Handbook for British Columbia. B.C. Ministry of Forests, Victoria.

Reily, P. W., and W. C. Johnson, 1982. The effects of altered hydrologic regime on tree growth along the Missouri River in North Dakota. Canadian Journal of Botany 60:2410-2423.

Rood, S. B., and M. L. Polzin, 2003. Big old cottonwoods. Canadian Journal of Botany 81:764-767.

Scott, M. L., G. T. Auble, and J. M. Friedman, 1997. Flood dependency of cottonwood establishment along the Missouri River, Montana, U.S.A. Ecological Applications 7:677-690.

Shaw, R. K., 1976. A taxonomic and ecologic study of the river bottom on St. Mary River, Lee Creek, and Belly River in southwestern Alberta, Canada. Great Basin Naturalist 36: 243-271.

Sieg, C. H., D. M. Meko, A. D. DeGaetano, and W. Ni, 1996. Dendroclimatic potential in the northern Great Plains, In Tree Rings, Environment and Humanity, edited by J. S. Dean, D. M. Meko, and T. W. Swetnam, pp. 295-302. Proceedings of the International Conference, Tucson, Arizona, 17-21 May 1994, Tucson, Radiocarbon.

Stahle, D. W., M. K. Cleaveland, and J. G. Hehr, 1988. North Carolina climate changes reconstructed from tree-rings: A.D. 372-1985. Science 240:1517-1519.

Stahle, D. W., and M. K. Cleaveland, 1992. Reconstruction and analsysis of spring rainfall over the Southeastern US for the past 1000 years. Bulletin of the American Meteorological Society 73:1947-1961.

Stahle, D. W., J. Villanueva-Diaz, D. J. Burnette, J. Cerano Paredes, R. R. Heim, Jr., F. K. Fye, R. Acuna Soto, M. D. Therrell, M. K. Cleaveland, and D. K. Stahle, 2011. Major Mesoamerican droughts of the past millennium. Geophysical Research Letters 38:L05703. Doi:10.1029/2010GL046472.

Stahle, D. W., D. J. Burnette, J. Villanueva-Diaz, F. K. Fye, R. D. Griffin, M. K. Cleaveland, D. K. Stahle, J. R. Edmondson, and K. Perkins, 2012. Tree-ring analysis of ancient baldcypress trees and subfossil wood. Quaternary Science Reviews 34:1-15.

Stockton, C. W., and D. M. Meko, 1983. Drought recurrence in the Great Plains as reconstructed from long-term tree-ring records. Journal of Climate and Applied Meteorology 22: 17-29.

Stokes, M. A., and T. L. Smiley, 1996. An Introduction to TreeRing Dating. University of Arizona Press, Tucson, Arizona; $73 \mathrm{pp}$.

Therrell, M. D., and M. Trotter, 2011. Waniyetu Wówapi: Native American records of weather and climate. Bulletin of the American Meteorological Society 92:583-592.

Thomas, G. P., and D. G. Podmore, 1953. Studies in forest pathology XI. Decay in black cottonwood in the middle Fraser Region, British Columbia. Canadian Journal of Botany 31:576-692.

Weakly, H. E., 1943. A tree-ring record of precipitation in western Nebraska. Journal of Forestry 41:816-819.

Weakly, W. F., 1971. Tree-ring dating and archaeology in South Dakota. Memoir no. 8. Plains Anthropologist 16:1-51.

Wigley, T. M. L., K. R. Briffa, and P. D. Jones, 1984. On the average value of correlated time series with applications in 
dendroclimatology and hydrometeorology. Journal of Climate and Applied Meteorology 23:201-213.

Woodhouse, C. A., and P. M. Brown, 2001. Tree-ring evidence for Great Plains drought. Tree-Ring Research 57:89-103.

Yu, P., H. Xu, M. Ye, S. Liu, J. Gong, H. An, and J. Fu, 2011.

Effects of ecological water conveyance on the ring increments of Populus euphratica in the lower reaches of Tarim River. Journal of Forest Research. DOI 10.1007/s10310-011-0312-3.

Received 29 January 2013; accepted 1 October 2013. 